\author{
И.О. Чугунова
}

\title{
ЧЕЛОВЕК НЕНАВИДЯЩИЙ: ПСИХОАНАЛИТИЧЕСКАЯ ДЕКОНСТРУКЦИЯ ФЕНОМЕНА НЕНАВИСТИ
}

\begin{abstract}
Аннотация. Внешняя феноменология ненависти, особенно её наиболее очевидные проявления - агрессия, социальные конфликты, насилие - мало что говорят о сути самого феномена. Его природа труднодоступна для сознательной ресрлексии и рационально-логического понимания. Обращение же к учениям о бессознательной психике открывает путь к пониманию тайн и парадоксов этого специфически человеческого явления, позволяет обнаружить его неразрывную спаянность с другими чувствами и страстями, и в первую очередь - диалектическую связь с любовью. В данной статье, делая обзор психоаналитических концепций ненависти, автор выстраивает понимание этой страсти как комплексного антропологического феномена, имеющего биологические, социальные и экзистенциальные корни. Автор соединяет две исследовательские методологии: первая опирается на парадигму теоретического психоанализа, а вторая - на традиции философско-антропологической рефллексии. Ненависть рассматривается как естественный элемент человеческой психики, играющий защитно-инициируюую роль на ранних стадиях её становления и охранительную - в период зрелости. Однако в социокультурных реалиях общества ненависть разрастается и становится деструктивной, искажая раскрытие человеческой природы и катализируя сочиальные бедствия. Образ "человека ненавидящего» представляется, с одной стороны, как неотделимая, хотя и вспомогательная ипостась личности, а с другой стороны, как особый антропологический тип, живущий во власти ненависти, для которого она-основа существования. Ключевые слова: ненависть, страсть, враждебность, любовь, либидо, мортидо, психоанализ, бессознательное, деструктивность, свобода.

Review. External phenomenology of hatred, especially the most obvious displays such as aggression, social conflicts and violence, says very little about the essence of the phenomenon. The nature of this phenomenon is difficult to be understood by the means of conscious reflection and logic. Appealing to the teachings about unconsciousness opens the way to understanding mysteries and paradoxes of hatred as a specific human phenomenon and uncovers the fact that hatred is intimately connected with other feelings and passions, first of all, it is dialectically connected with love. Reviewing psychoanalytical theories of hatred, the author develops the concept of hatred as a complex anthropological phenomenon with biological, social and existential roots. In her research Chugunova combines the two research methodologies, the first one is based on the paradigm of theoretical psychoanalysis and the second one is based on the tradition of philosophical anthropological analysis. Hatred is viewed as a natural element of human psyche. It performs a defensive and initiating function at early stages of the development of human psyche and protective function at the stage of maturity. However, social and cultural effects of the society expand hatred and make it destructive, thus distorting human nature and catalyzing social disasters. On the one hand, the image of 'hateful human' is viewed as an inseparable yet ancillary feature of personality, on the other hand, it is a special anthropological phenomenon creating the basis for hatred.
\end{abstract}

Key words: unconsciousness, psychoanalysis, mortido, libido, love, animosity, passion, hatred, destructiveness, freedom.

\section{Человеческие страсти и роль психоанализа в их исследовании}

Страсти - краеугольный вопрос человеческого бытия. Трепетная любовь, клокочущая ненависть, испепеляющее любопытство, бурный энтузиазм, жгучая месть... Образ человека немыслим без страстей - этой квинтэссенции чувственности. Без доли страстности, привносимой в человеческую деятельность, невозможны достижения культуры 


\section{Психопатология повседневности}

и цивилизации. Человек призван и в то же время обречён предаваться страстям, испытывая увлечённость и творческий экстаз, совершая подвиги и впадая в безумства.

Современный мир, как может показаться, тяготеет к бесстрастности: мы идеализируем технику, превозносим рационализм, наша обыденность запрограммирована и всё менее спонтанна, обществом культивируется поверхностность эмоций. Однако подобная девальвация чувственности отнюдь не означает истребления страстей: более того, что касается страстей негативных, - они лишь пролиферируют на этом фоне. Ненависть - одна из них. Будучи в числе самых деструктивных, она вездесуща и неистребима. Это близкий спутник человека и общества, и во многом незримый: те феномены, которые мы наблюдаем под видом агрессии, конфликтов, насилия, - лишь вершина айсберга. Истинная глубина и мощь этой страсти гораздо больше, чем обычно представляется. Именно поэтому задача разобраться в сути феномена ненависти является остро актуальной. И именно в силу невероятной глубины и скрытости феномена мы ищем помощи у психоанализа.

Психоанализ играет особую роль в исследовании ненависти. Хотя этим явлением с разных сторон сегодня интересуется всё больше направлений социальной и гуманитарной мысли, именно психоанализу принадлежит дерзновение проникнуть в глубинные истоки происхождения враждебных страстей, кроющиеся в бессознательных слоях человеческой психики. Психоанализ уникален спаянностью теоретического изучения человека и клинических исследований, где страсти проступают не только в их «нормальном» существовании, но и в патологии - в своём преувеличенном виде, служащем наглядной моделью изучения нормы.

Психоанализ раскрывает перед нами тайны страстей - в их динамике, метаморфозах, противоборстве и диалектическом единстве. Как отмечал Э. Фромм, именно психоанализ, и, в первую очередь, в лице Фрейда, впервые взялся за научное исследование «всего богатства человеческих страстей - любви, ненависти, тщеславия, жадности, ревности и зависти», которые ранее «были «доступны» лишь романтикам и трубадурам» [1, с. 25].

Осмысления, почерпнутые из психоаналитических концепций, с необходимой примесью философско-антропологического взгляда позволят нам глубже понять природу такой удивительной, парадоксальной страсти как ненависть, просле- дить механизмы душевных движений, несущих ненавистническое, и, быть может, поникнуть в сакральные тайники одиозности этого причудливого состояния.

Мы исходим из того, что ненависть - и чувство, и страсть. Чувство - поскольку она выражает некое отношение человека к объекту, явленное на языке переживания, часто мультимодального - в виде эмоций, образов, ощущений. Страсть - поскольку это чувство способно прорасти в человека, стать интенсивным и превратиться в доминанту его сознания, в одержимость, толкающую его в определённом направлении. Говоря так о ненависти, мы намеренно уходим от её понимания как простой эмоции и аффекта. Такой подход мы считает редукционным: конкретные эмоции и их внешние выражения, - к примеру, гнев, ярость или агрессивные выпады, - лишь компоненты, а точнее, феноменологические маркеры ненависти. Это сложное явление явно не ограничивается ни самой по себе сферой эмоций и аффектов, ни отдельно взятой областью ценностей и мотивов, ни, точно так же, когнитивной сферой. Эта страсть, впрочем, как и любая другая, есть нечто комплексное, вовлекающая человека в своё поле и овладевающая его волей, являясь причиной множества внешних эмоциональных и поведенческих феноменов, часто исследуемых по отдельности. Это, к примеру, такие общие феномены как агрессия или конфликты, или, наоборот, явления частного порядка - ксенофобия или так называемые убийства на почве ненависти.

Интересное образное различение аффектов и страстей приводил ещё И. Кант: «Аффект действует как вода, прорывающая плотину; страсть действует как река, всё глубже прокапывающая своё русло. <..> Аффекты честны и открыты, страсти же коварны и скрытны» [2, с. 328]. Действительно, страсть - нечто более «глубоководное», постоянное и скрытое, чем то, что мы наблюдаем «на поверхности. Именно поэтому мы и обращаемся к психоанализу, способному приоткрыть «изнанку» подобных явлений.

В психоанализе много внимания уделено ненависти. И, вместе с тем, в нём не найти её единого толкования. Главная причина состоит в том, что психоаналитическая мысль в своём развитии есть не что иное как определённая смена парадигм, последовательное развитие взглядов на природу человека. Здесь мы будем иметь дело с различными ракурсами рассмотрения ненависти, чтобы затем попытаться соединить их в единую объемную кар- 
тину данного феномена. Не претендуя на полноту исследования, в этой статье мы постараемся деконструировать ряд важных психоаналитических идей о природе этой человеческой страсти.

\section{Диалектика любви и ненависти}

Рефлексия связи ненависти и любви, безусловно, начинается с утверждения их противоположности. Однако продолжая рассуждение диалектически, мы находим в их взаимоотношениях более глубокие слои. Отголосок этой связи мы видим в расхожей формуле «от любви до ненависти - один шаг», в этом контексте не лишённой смысла. Рассмотрим, как идея диалектики этих полярных страстей развернулась в психоаналитической мысли, берущей истоки, в свою очередь, в мысли философской.

Любовь занимает «привилегированное положение в азбуке страстей» [3, с. 30]. Это чувство во все времена вдохновляло творцов и исследователей: воспевалось в искусстве, становилось центром внимания философских размышлений. Идея исследования любви проникла и в гуманитарную научную мысль. Теория либидо 3. Фрейда сегодня знакома самой широкой публике. Согласно этому учению, инстинктивной основой человеческой жизни является Эрос, чья неутолимая энергия любви (либидо) направляется на продолжение рода, обновление жизни и, в более широком понимании, на все виды созидания.

Однако не столь общеизвестно, что позже Фрейд расширил свою теорию. Сталкиваясь с клиникой явлений, малообъяснимых с позиции теории либидо, таких как садизм и мазохизм, а также пережив ужасающий опыт Первой мировой войны и ряд личных потрясений (смерть дочери и собственное заболевание раком) [4], он перешёл к более пессимистичным воззрениям на природу человека, выдвинув идею влечения к смерти - Танатоса. Это был второй, с точки зрения Фрейда, не менее фундаментальный инстинкт, чья энергия, позже названная «мортидо», направлена на разрушение и прекращение жизни.

Ещё менее известным является факт, что в психоаналитическом сообществе на тот момент уже звучали схожие идеи у К. Юнга, Э. Блейлера, В. Штекеля, а приоритет в самом открытии влечения к смерти принадлежит Сабине Шпильрейн. Она впервые прямо высказала мысль, что в каждом стремлении к созиданию одновременно есть и им- пульс к разрушению, распаду: зарождение нового знаменует и являет собой результат отмирания старого [5]. Конкретизируя эту идею применительно к страстям, исследовательница писала, что во всяком наслаждении есть доля отвращения, а в страстной любви таится образ уничтожения. Присутствие деструктивного в «нормальном» либидозном влечении у человека едва уловимо. Однако сверхсильный накал страсти находит разрядку только в разрушении, что мы видим, к примеру, в трагедии о Ромео и Джульетте.

Ещё до признания Танатоса базовым влечением, в своих ранних работах Фрейд писал об амбивалентности побуждений и чувств [6; 7; 8]. Тесное сосуществование полярностей любви и ненависти особенно выражено у детей и первобытных людей, а также в психопатологии, где эта двойственность концентрируется в остром конфликте, ищущем разрядки в симптомах душевных расстройств. В фундаментальном исследовании тотемического уклада жизни дикарей Фрейд обнаруживает амбивалентность чувств примитивных людей к табу священному запрету [8]. А случай маленького Ганса - широко известная хрестоматийная иллюстрация эдипова комплекса - повествует о двойственном переживании мальчика по отношению к отцу. В этом чувстве слились воедино и любовь, и желание отцу смерти. Напряжение аффектов было столь велико, что попытки их обуздания привели ребёнка к фобии лошадей, т.е. объекта, на который спроецировались его вытесненные из сознания негативные переживания [7].

Нельзя здесь не вспомнить, что сама диалектическая идея единства и антагонизма любви и ненависти родилась задолго до психоанализа - первые яркие примеры мы находим уже в древности. Так, взаимосвязанность этих полярностей была мифопоэтически описана Эмпедоклом в V в. до н.э. Бытие всего универсума он видел как господство двух сил - любви и ненависти. Любви здесь принадлежит роль вселенской консолидации: она сплачивает и преодолевает разрозненность и вражду, приводит к гармоническому согласию и одухотворенному единству. Ненависть, напротив, разобщает и расчленяет целое на бездушное множество разрозненных частей, повергает гармонию в хаос. Таким образом, жизнь разворачивается как «грандиозная драма, мировая борьба (агон), в которой поочередно берут верх то положительные силы любви и примирения, то отрицательные силы вражды и ненависти» [9, с. 101]. 


\section{Психопатология повседневности}

Эти ранне-античные гилозоистические представления, в которых любовь и ненависть являются лишь «стихиями» мира, представляют собой продуктивную метафору динамики человеческих страстей. Подобно спонтанной энергии универсума, энергия психическая бушует и движется внутри человеческого микрокосма, адресуясь к его объектам любви или ненависти, вдыхая жизнь в человеческие чувства и делая отношения человека с миром проникнутыми неравнодушием и страстностью.

Взаимосвязь любви и ненависти - одна из «вечных» диалектических тем. Она ярко прозвучала, в частности, в немецком идеализме. Ф. Шеллинг, развивая свою «философию тождества», постулировал единую праоснову всех противоположностей. Только первоначально сотворённое единство противоположных страстей даёт базис для существования каждой отдельной страсти: «тот, в ком нет ни материала, ни сил для зла, не способен и к добру» [10, с. 144]. Философ подчёркивал, что «каждая сущность может открываться в своей противоположности» [10, с. 121], и, в частности, любовь имеет с ненавистью «общий корень» и может существовать «только в ненависти». Ему же принадлежит и известный афоризм: «Душа всякой ненависти есть любовь» [10, с. 145].

В русской философии нечто подобное было глубоко осмыслено В.С. Соловьёвым. Раскрывая свою доктрину «всеединства», он говорил о взаимодействии двух начал. Одно из них - первооснова жизни - это эгоизм, обособление от других, вражда и ненависть, «злобные нарушения и захват чужого бытия». «Каждое существо в нашем мире, - пишет мыслитель, - <...> всею своею природною жизнью говорит одно: я есмь и всё остальное только для меня, и, сталкиваясь с другим, оно говорит ему: если я существую, то тебе уже нельзя существовать, тебе нет места со мною» [11, с. 351]. Следствие этого - всемирное зло, раздоры, хаос и бессмыслие. Второе, противоположное начало «невольное влечение единящей силы», «стремление или влечение к другому» [11, с. 354]. Это единение, неотделимое от всеобъемлющей вражды, философ называет «смыслом мира». У животных этот смысл реализуется стихийно: раздирая добычу, животное с ней соединяется, хотя и «не знает этого смысла», и также безотчётно «соединяясь с общей жизнью в родовом инстинкте, особь невольно и слепо жертвует собою для рода, теряет себя в нём» [11, с. 357]. Природная часть в человеке также враждует с миром и одновременно воссоединяется с ним. Однако благодаря сознанию, Логосу человек наполняет как враждование, так и влечение Идеей, творя осмысленные отношения с миром - отношения человеческой ненависти и любви.

Именно этот фундаментальный принцип - неразрывность любви как интегрирующего начала и ненависти как начала диссоциирующего, ухваченный в философии прошлых веков, позже стал одним из центральных в психоаналитическом изучении страстей, где он стал рассматриваться через внутренний конфликт и попытку его разрешения.

\section{Базовый конфликт: любовь и ненависть с позиции Фрейда}

Отношения человека с миром и самим собой, построенные на основе диады «любовь-ненависть», в психоаналитической трактовке образуют фундамент личности. 3. Фрейд, как основоположник психоанализа, положил начало традиции понимания этих двух страстей как корневых по отношению к широкому спектру иных чувств. Он исходил из теснейшей связи любви и ненависти с природными, биологическими влечениями. Те, в свою очередь, нанизываются на два полярных базовых состояния организма - удовольствия и неудовольствия. В самом начале душевной жизни человеческое «Я» живёт по принципу удовольствия: оно аутоэротично и не нуждается во внешнем мире. Однако инстинкт самосохранения не позволяет ребёнку изолироваться от внешнего мира: он вынужден обращаться к нему, сталкиваясь не только с источниками удовольствия, но и раздражения (принцип реальности). Обращаясь к объектному миру, психика ребёнка прежде всего стремится интроецировать (включить в себя) объекты, являющиеся источником наслаждения, - иными словами, слиться с ними [12]. Неприятные ощущения от объектов младенец, напротив, «отбрасывает во внешний мир и ощущает его как враждебный» [12, с. 144]. Более того, травмирующие переживания ребёнок проецирует (переносит) на объекты внешнего мира, «наделяя» их неприятными свойствами и приписывая им часть негативной энергии своих собственных агрессивных влечений. Так, по мнению психоаналитика, закладывается первое чувство ненависти в человеке.

Мир младенца, распадаясь на наслаждающееся, нарциссичное Я и враждебную внешнюю реальность, цементирует ту аффективную напряжённость, в поле которой будет протекать вся его 
дальнейшая жизнь. Фрейдовская теория ставит нас перед неприятным выводом: внешний мир, в отличие от собственного аутоэротического Я, является индивиду изначально враждебным, а вовсе не индифферентным и, уж тем более, не дружественным и полным любви.

Как пишет Фрейд, ненависть, будучи проявлением отношения к внешнему миру, оформилась раньше, чем любовь: ненависть «старше любви» $[12$, с. 148]. Объекты же наслаждения поначалу вызывают у младенца отнюдь не любовное чувство, предполагающее восхищение ими и желание заботится о них. Чувство, именуемое нами как «любовь», противоположное понятию «ненависть», по Фрейду, зарождается только на более поздней стадии - генитальной. Первые же либидозные притяжения к объектам несут иной смысл: «расширение» собственного «Я», что в этот период младенчества означает не что иное как стремление поглощать объекты, овладевать ими, не заботясь о том, «будет ли при этом поврежден или уничтожен объект» [12, с. 148]. Рассуждая таким образом, Фрейд делает парадоксальное заключение, что на первых стадиях любовь, едва выделившись из единого, пока нерасчленённого влечения, мало отличима от ненависти.

В данной трактовке человеческая ненависть и агрессивность - наиболее глубокий корень всех человеческих страстей. Уже на заре существования индивида ненависть узурпирует значительную часть его психической энергии, создавая предзаданность к враждебности, и бросая тем самым человеческому существу непростой вызов.

Неся в себе это разрушительное бремя с первых шагов жизни, мы не можем не задаваться вопросом о его сакральном значении. И фрейдовская теория даёт нам ответ. То, что, на первый взгляд, потрясало своей неприятной иррациональностью, обретает наконец свой объяснимый, утилитарный и глубокий смысл. Архаичная роль ненависти состоит в первоначальном отстранении собственного Я от внешнего окружения, ограждении его от потенциально враждебной реальности, обособлении и выделении Я из пока мало расчленённого младенческого мира. Наконец, напряжённость между полюсами ненависти и любви являет собой силовое поле, напитывающее Я энергией, необходимой ему для развития в реальном мире. Созревая до уровня, где становится возможной любовь (а это соответствует генитальной стадии), человек, благодаря опыту ненависти, уже противопо- ставлен внешней реальности, развёрнут в сторону самосохранения и самоутверждения. Таким образом, архаичные агрессивные чувства, пропитанные ранними ненавистническими переживаниями, закладывают не только всем известные бремя и опасность, но и несут для становления человека необходимое благо.

Слитность любви и ненависти сопровождает нас всю жизнь. Единый генетический корень любви и ненависти проявляет себя даже в зрелых человеческих чувствах: в них остаются те самые рудименты младенческих нерасчлененных отношений с миром - в любви чаще всего есть примесь ненависти, отражающая интересы самосохранения и самоутверждения «Я». Именно поэтому, как отмечал Фрейд, «если любовные отношения к какому-нибудь объекту обрываются, то нередко вместо них появляется ненависть, отчего у нас получается впечатление превращения любви в ненависть» $[12$, с. 149]. Присутствие ненависти в качестве «нерушимой» подоплеки обусловливает и парадоксальную неуничтожимость любовных отношений: рухнувшая любовь может продолжать своё существование как ненависть.

Развивая двойственное понимание человеческой природы, Фрейд пришёл к выводу, что вся жизнь человека, равно как и вся человеческая культура представляет собой процесс и результат постоянной борьбы между Эросом и Танатосом. Обоим началам здесь принадлежит важная роль. Фрейд призывает не торопиться с прямой трансформацией этих понятий в Добро и Зло. Он пишет: «Оба эти влечения в равной мере необходимы, их взаимодействие и противодействие порождает явления жизни. И дело обстоит таким образом, что едва ли когда-нибудь одно из этих влечений может проявить себя изолированно, оно всегда связано с некоторой примесью с другой стороны <...>. Так, например, инстинкт самосохранения является, без сомнения, эротическим по своей природе, но именно он нуждается в агрессивности, чтобы претвориться в жизни» $[13$, с. 332$]$.

\section{Ненависть как вызов психике: взгляды М. Кляйн}

Последователи Фрейда внесли существенный вклад в развитие взгляда на дуалистическую природу любви-ненависти как основу становления отношений человека с миром. Так, К. Абрахам рассматривал враждебное отношение к объектам как 


\section{Психопатология повседневности}

одну из необходимых ступеней индивидуального развития (анально-садистическая фаза), позже сменяющейся более зрелым отношением к миру, характеризующимся способностью сохранять и оберегать объекты от разрушения. И любовь здесь является воплощением этой зрелости.

Мелани Кляйн продвинулась ещё глубже в своих исследованиях механизмов любви и ненависти. Заметим, что тема ненависти как таковая вообще занимает одно из центральных мест в её исследованиях. Будучи ученицей К. Абрахама, а также Ш. Ференци, Кляйн во многом отталкивалась от их находок в понимании динамики развития человеческих чувств. Продолжая традицию дуализма инстинктов жизни и смерти, исследовательница даёт начало концепции «объектных отношений», в которой идёт речь о ранних отношениях ребёнка с миром окружающих объектов. Отпечатываясь в глубинах психики субъекта, эти отношения формируют его внутренний мир на всю жизнь.

Источник деструктивных импульсов, по мнению Кляйн, кроется в самом ребёнке: в нём заложены зародыши негативных страстей - ненависти, зависти, жадности. Это его первая защита в небезопасном, несовершённом и далёком от идеала реальном мире. Рождение в реальный мир из идеального, безобъектного мира материнской утробы вызывает у ребёнка неминуемую тревогу и «ностальгию по пренатальному состоянию» [14, с. 16]. Движимый этой тревогой, ребёнок жаждет найти «хороший» объект, дающий удовлетворение и приближающий к потерянному идеалу. «Плохие» объекты он яростно, ненавистнически отторгает.

Вдумаемся в смысл кляйнианского деления на «хороший» и «плохой» объекты. Прежде всего здесь речь идёт о любви и заботе матери о ребёнке. «Хороший» объект - это любящая мать, источник питания, удовлетворения, чувства безопасности. Именно такой объект жизненно важен для закладки здорового, устойчивого ядра психики. «Плохой» объект - мать игнорирующая или ненавидящая. Даже слишком тревожная, депрессивная или эмоционально неуравновешенная мать - тоже «плохой» объект: она чрезмерно обостряет и без того ощутимую врождённую тревогу малыша, подтачивая чувственную основу его доверия к миру.

Если мы выйдем за пределы психоаналитического контекста, то становится очевидным и иной смысл такого деления: это и противопоставление жизни и смерти, прообразов добра и зла. Младенец и мать в определённом смысле включены в борьбу этих двух сил: сложная драматургия индивидуального становления человека разыгрывается именно в пространстве этих полюсов. «Хороший» объект призван стать в жизни человека «прототипом материнской доброты, неистощимого терпения и щедрости, а также творчества» [14, с. 18]. Для формирования устойчивого Эго требуется прочное укоренение «хорошего» объекта в психике ребёнка, - другими словами, укоренения в нём любви и заботы, силы и терпения, способных защитить и смягчить врождённую тревогу. Только такая личность сможет обладать здоровым чувством самоценности, будет способной к преданности людям, духовным ценностям и продуктивному созиданию. «Плохая» мать, недодающая любви, принятия, уверенности и заботы, подрывает интеграцию Эго. Детское Я становится шатким, неспособным овладевать своими порывами - ненавистью, завистью, жадностью. В некоторой степени присутствующие и «в норме», здесь эти чувства начинают непомерно разрастаться, мешая становлению образа «хорошего» объекта, и, следовательно, доверия к себе и окружающим, способности к любви, сопереживанию и благодарности. Слабое Я становится лёгкой добычей страстей ненавистнического спектра: такая личность отравлена запертой внутри враждебностью. Ненависть становится незримым фоном её дальнейшего существования.

Акцентируем внимание на важной идее, вытекающей из теории Кляйн и, в неявной форме, сквозившей уже в работах Фрейда. Это идея априорности негативных чувств, их изначальной заложенности в человеческую природу. Человеку «дана» способность испытывать ненависть и зависть, жадность и ревность, вместе со способностью тянуться к ощущению счастья и любить. Это очень глубокая идея: ведь именно через постижение зла, борьбы с ним как с вызовом происходит знакомство человека с реальным миром, природа которого так же дуальна. Именно через противостояние ненависти формируются и обогащаются отношения с реальными объектами в их разнонаправленной валентности. Замысловатая палитра ненавистнических чувств придаёт остроту и специфически человеческий облик недифференцированным и безликим врождённым деструктивным влечениям. Кляйн мало говорит об аспектах социальности, однако этот пласт человеческого здесь, тем не менее, незримо присутствует: именно в разнообразии проявлений враждебных чувств младенца уже намечается сложный рисунок взаи- 
модействия между Я и другими людьми, который может служить прообразом будущих социальных отношений.

Коснёмся теперь сути механизма разрешения конфликта любви и ненависти, испытываемого к одному и тому же объекту. Модель этого механизма чрезвычайно интересна. Как пишет Кляйн, чтобы сохранить важнейший объект (образ матери), младенец проходит через опыт отщепления «плохой» (и даже ужасной, угрожающей) матери от «хорошей» (идеальной). Ребёнок пока не в состоянии справиться с конфликтом противоположных чувств, столь сильных для его ещё хрупкой психики: он вынужден «держать» их обособленно друг от друга, то переживая абсолютную любовь, то столь же радикальную ненависть. Этот опыт изоляции ненависти от любви необходим для стабилизации, выживания психики, однако затем маленькому существу предстоит постепенно интегрировать эти два противоположных чувства, синтезируя образ реального объекта - «настоящей» матери: и любящей, и несовершённой одновременно. На этом этапе у ребёнка единственный путь - внутренне «оплакать» [14, с. 40] потерю идеала, чтобы приблизиться к реальности и в дальнейшем смочь справиться с ненавистью и другими враждебными чувствами, смягчая их любовью, сочувствием, благодарностью, терпением.

Но этого «оплакивания» может не произойти: ему могут помешать постоянные фрустрации со стороны внешнего мира и, соответственно, чрезмерные, не проходящие ненавистнические чувства, формирующие избыточное расщепление. Результаты поистине трагичны: приближения к реальности не происходит, и психика остаётся в патологически защитном - расплывчатом и раздробленном - состоянии, т.е. во власти скрытых, невыраженных, а потому неуправляемых страстей. Глубоко отщеплённая, «непереваренная», неуравновешенная любовью ненависть подавляет жизненную энергию. Наплывы этой ненависти ищут выплеска в действиях, кажущихся окружающим «немотивированными». Ядовитая зависть, истощающая жадность и ранящая ревность - единое созвездие страстей, вкупе с ненавистью, знаменуют уход человека от творческой, свободной и ответственной жизни, несут обесценивание того, что могло бы переживаться как благо. Они же и лишают индивида искренних и добрых отношений с окружающими и самим собой.
Толкование ненависти у М. Кляйн как результата её несостоявшейся интеграции с любовью, на наш взгляд, весьма глубоко раскрывает тему диалектической сопряжённости ненависти и любви, хотя это и происходит на специфическом языке психоанализа и речь здесь идёт о ранней фрустрации и фиксации на параноидно-расщеплённой стадии. Выходя за рамки клинического языка, подытожим, что любовь и ненависть, эти страстиантиподы, подобно силовым полюсам, должны «найти друг друга» в едином поле внутреннего мира человека, чтобы вместить в себя настоящую, а не вымышленную реальность, дуальную по своей сути. Если этого не происходит, человеческая природа недополучает своего раскрытия, недовоплощается, и человек не обретает целостности в своём индивидуальном становлении, неся в жизнь чрезмерное бремя разрушительных страстей и страдая от недостатка любви. Современный исследователь П. Куттер, посвятивший труд психоанализу страстей, на примере выходцев из детского дома - озлобленных, «бессердечных», склонных к насилию справедливо замечает: у тех, чья душа поражена ненавистью, обманутая «жажда любви никогда не утихает» $[3$, с. 56].

Идея отщепления негативных аффективных комплексов очень распространена в психоаналитическом обиходе. Современные психоаналитики исследуют механизмы субличностей, тяготеющих к внутренней автономии и становящихся плохо управляемым источником агрессивных страстей. Так, Д. Калшед, приверженец юнгианской школы, посвятил отдельный труд исследованию природы внутренних агрессивных источников травмированного Я: архетипическая сила, и нападающая, и оберегающая одновременно - позволяет ребёнку выжить, и рудименты внутренней агрессии и ненависти к себе и миру есть не что иное как плата за факт выживания в тяжелых травмирующих условиях [15]. О. Кернберг, во многом опиравшийся на идеи Кляйн, писал о ненависти как оборотной стороне страдания, следствии прошлых предательств и унижений. Человек, идентифицируясь с глубоко укоренённым в нём «плохим» внутренним объектом, сам становится мстительным преследователем. И то, что изначально проявлялось как здоровая ярость, впоследствии стало ненавистью [16].

Подобные исследования, конечно, касаются тяжело травмированной психики. Однако, как мы говорили в начале статьи, психопатология является всего лишь предельной моделью так называе- 


\section{Психопатология повседневности}

мой нормы. Однако здесь закономерно возникает и такой вопрос: а является ли «нормальной» та ужасающая феноменология ненависти, которой переполнен мир? Сомнительно, что найдутся аргументы в поддержку этой «нормы».

\section{От идеи мортидо к пониманию ненависти}

Когда мы, вслед за Фрейдом, проводим параллель между двумя антиномиями Эрос-Танатос и любовьненависть, мы сталкиваемся с невольной игрой понятий, искушающей нас объявить инстинкт смерти прямым источником ненависти. Остановимся чуть подробнее на этом вопросе.

Утвердившись в открытии влечения к смерти, Фрейд стал трактовать всю гамму разрушительных страстей исключительно как выплеск этого влечения, обычно вытесненного и скрытого. «Инстинкт ненависти и уничтожения» он рассматривал как конкретизацию «обобщённого агрессивного или деструктивного влечения» [13, с. 331].

При этом Фрейд пошёл ещё дальше. Излагая новую идею, он писал «всё живущее <...> возвращается к неорганическому, <...> целью всякой жизни является смерть» [17, с. 405]. Он настолько заострил проблему, что сила Танатоса стала казаться мощнее и фундаментальнее, чем сила Эроса. Все ранее описанные им «сторожа жизни» - влечения к удовольствию, самосохранению, власти и самоутверждению - были объявлены им «частными влечениями, предназначенными к тому, чтобы обеспечить организму собственный путь к смерти» [17, с. 406].

Выдвинутый Фрейдом принцип действительно отличается явной всеохватностью и предельностью. Излишне говорить, но он создаёт заманчивую перспективу объявить мортидо детерминантой любых негативных чувств и порывов, в том числе и ненависти как источника разрушений. Да и как иначе: вся кровавая человеческая история, полная войн и, в особенности, минувший век, с его ужасами геноцида и ядерной угрозой, предстаёт перед нами самым реальным и трагическим доказательством того, что человек способен подвести роковую черту под существованием своего биологического вида. И уж тем более убедительными в этом вопросе видятся феномены саморазрушения у отдельно взятого человека: в патологии это, к примеру, компульсивная тяга к страданию и самоповреждениям, навязчивое стремление к риску, а в так называемой «норме» - в изобилии окружающие нас банальные «вредные привычки».
Безусловно, гипотеза о существовании мортидо, выдвинутая Фрейдом, сразу вызвала дискуссии и возражения в психоаналитическом сообществе, не утихающие и по сей день. И в то же время неудивительно, что сразу нашлись и её преданные адепты. Как мы помним, М. Кляйн поставила во главу угла именно влечение к смерти: согласно её теории, именно это влечение, под маской таких саморазрушительных побуждений как зависть и ненависть, бросает вызов зарождающейся человеческой субъектности. Идею влечения к смерти также подхватил и П.Федерн, кто, собственно, и дал ему это теперь уже бессмертное название «мортидо» [18]. В продолжение этой традиции позднее даже появился концепт «деструдо», предложенный А. Вейссом [18]. Идея продолжала жить и в других, более поздних течениях аналитической мысли. К примеру, она высветилась в экзистенциальном анализе как проблема «бытия-к-смерти» [19, с. 190].

Среди психоаналитиков, придерживавшихся парадигмы влечений, было немало и тех исследователей негативных сторон человеческой природы, кто не признавал существование мортидо, как, например, Д. Винникотт, связывавший агрессию и ненависть с влечением к жизни [20].

Сложно отрицать тот очевидный факт, что ненависть идёт рука об руку с тенденциями разрушения - как реального, так и символического. Ненависть, обрастая силой яростного аффекта, заряжает человека жаждой мести, унижения, уничтожения, ликвидации. Но вопрос остаётся открытым: можем ли мы считать ненависть прямым наследником мортидо?

Ответ мы вряд ли найдём в ортодоксальном психоанализе, сосредоточенном на биологически врождённых истоках психики. Его объяснительные возможности ещё могут «справиться» с пониманием агрессии, если мы дефинируем её как биологически запрограммированную реакцию на опасный стимул. Агрессивное биологическое начало в человеке, безусловно, сопряжено с ненавистью: оно способно придать этой страсти энергию, динамику, животную мощь. Однако феномен ненависти, как и человеческой деструктивности в целом, неизмеримо сложнее. Если мы ограничим понимание натуры человека только рамками заложенных в нас биологических влечений, мы потеряем саму суть человеческого. Человек не только природное существо. Ниже в статье мы разберём другие измерения человека. В контексте же разговора о мортидо мы вынуждены подытожить, что ненависть не явля- 
ется дериватом влечения, сколь бы удобной ни казалась нам эта идея. И, вместе с тем, мы отнюдь не отрицаем, a, напротив, подчеркиваем саму роль смерти, влияние на человека факта её присутствия в человеческой жизни. Для нас это неотвратимая угроза и предмет тайного страха, негаснущий маяк и вечная антропологическая загадка. Однако мы бы не стали утверждать, что смерть является человеку под маской мортидо - животного влечения. И что он только подспудно тянется к ней, смутно испытывая внутри себя толчки тёмных побуждений. Ведь смерть обретает в человеческом мире символическую, духовную огранку, очищенную от физиологической подосновы. Мы видим это в образах искусства или, к примеру, в знаменитом приветствии монахов-траппистов в XVII в.: «memento mori».

Новый психоанализ во многом преодолел ограничения классического фрейдизма, сместив фокус внимания на социокультурные стороны человеческой природы. Но заслуга Фрейда, тем не менее, продолжает оставаться в том, что он дал начало традиции диалектической рефлексии любви и ненависти в психоанализе, пусть и через физиологический принцип влечений, являвшийся, к слову, необходимой данью научному менталитету того времени. Именно такой угол рефлексии определил то поле, в котором ненависти отводится осмысленная и созидательная роль. Согласно этой позиции, человек обязан ненависти своим развитием, приспособлением к жизни. А именно - обязан раннему опыту ненависти, с которым ему неминуемо приходится столкнуться. Природная энергия жизни, сталкиваясь с энергией смерти, диалектически отрицает своё отрицание, справляясь с этой угрозой и даруя человеку жизнеспособность в окружающем мире. Энергия же смерти, пусть и под маской ненависти, неустанно будоражит жизнь, становясь её мощным катализатором.

\section{Между я и ты: социальные аспекты ненависти}

Реформация классического фрейдизма перенесла акценты на социальную природу человека. В противовес пониманию, что в человеческой природе уже «заложены» определённые деструктивные инстинкты, неофрейдисты обратили внимание на решающее влияние социальной среды - окружения, в котором формируется индивид. Среди сторонников этой позиции особый интерес для нас представляет К. Хорни: ненависть является одним из центральных концептов в её теории.
Исследовательница ввела понятие «базовая тревога», а ненависти отвела первое место среди провоцирующих её причин. Данный взгляд отличался от теории биологических влечений прежде всего следующим. То, что во фрейдизме трактовалось как нормальные влечения, у Хорни рассматривается как навязчивые побуждения невротика, вторичные по отношению к укорененной в нем ненависти. Все невротические страсти, в том числе, безусловно, и ненависть, она считала производными от качества человеческих взаимоотношений. Ведь всё, чем человек является, - не результат врождённых животных сил, а плод социализации человека.

Ненависть, согласно Хорни, прорастает внутри человека в детстве, на фоне недостатка любви и уважения со стороны окружающих, развиваясь и усиливаясь в ходе столкновения индивида с собственным несовершенством и слабостью на фоне других людей. Она вызывает мучительные чувства тревоги, беспомощности и неуверенности в себе, а те, в свою очередь, провоцируют новые волны ненависти - и к себе, и к окружающим. Круг замыкается.

Хорни реконструирует тонкую «механику» ненависти. Описываемый ею внутренний конфликт замешан на столкновении трёх внутренних частей человеческого Я: Я идеального, Я реального (наличного) и Я подлинного. На первом плане - ненависть атакует «досадное» наличное Я, в своём несовершенстве служащее помехой «возгордившемуся идеальному Я», которое и оборачивается к наличному Я, этому «чужаку», с ненавистью и презрением. Однако за этим конфликтом прячется ещё более глубокая драма: это столкновение самой гордыни и подлинного Я, отстоящего гораздо дальше и от Я идеального, и от Я наличного. Это «вечный подземный источник ненависти к себе» [21, с. 107]. Глубокое неприятие себя, поддерживающее структуру невроза, оборачивается тяжкой тиранией, отрезающей человека от его конструктивной энергии жизни. Исследовательница пишет: «Ненависть к себе делает видимым раскол личности, начавшийся с сотворения идеального Собственного Я. Она означает, что идёт война. <...> это - существенная характеристика каждого невротика: он воюет с самим собой» [21, с. 106].

Хорни не случайно делает центральный акцент именно на ненависти человека к самому себе, а не к вешним объектам. Ведь враждебность, «развёрнутая наружу», по её мнению - лишь частный случай аутоненавистнических чувств. Направлен- 


\section{Психопатология повседневности}

ная «на жизнь, судьбу, общественные институты или на людей», ненависть являет собой лишь попытку ослабить внутренний конфликт, переводя его в межличностный. То же происходит и в другом случае переноса ненависти вовне: человек проецирует собственные враждебные чувства на других, делая их ненавистниками, а себя - жертвой этой неприязни [21]. Этот универсальный защитный механизм проекции работает в отношении любых не признаваемых человеком собственных чувств. В предыдущей статье мы уже касались темы проекции архетипа Тени, трактуя ненависть в юнгианском ключе [22]. Не я, а образ другого человека «принимает» на себя наши вытесненные страсти и стремления, природа которых низка и примитивна. Не я, а другой пусть будет средоточием зла. Как указывал П. Куттер, именно так обрастают злом образы «преступников», «сумасшедших», «чужаков», «иностранцев», «евреев» [3, с. 106]. Таков один из самых распространённых механизмов ненависти в обществе.

Этот же механизм ценностной атрибуции мы видим и при превращении любви в ненависть. Если любовь - это открытие ценностей в объекте, то ненависть, - напротив, его радикальное обесценивание. Один из основоположников философской антропологии М.Шелер писал: ненависть есть «превращенная любовь» [23, с. 369]. Всякая ненависть, сколь бы она ни была связана с «антиценностями», изначально проистекает из любви к этим ценностям.

Затронем ещё одну любопытную тему, волновавшую как Хорни, так и многих других психоаналитиков [3; 16; 24]. Это вопрос взаимосвязи ненависти с другими невротическими страстями. Взять, к примеру, властолюбие, зависть и тщеславие, стремление к статусу и обладанию. Подобные устремления служат защитой от тревожности, хаоса эмоций, позволяя сублимировать мощный заряд ненависти, держать в себе который невыносимо. Порой это приобретает ужасающие деструктивные формы: не только желание доминировать, подчинять своей власти и контролю, но и унизить и стереть с лица земли, устраняя любой намёк на ответную агрессию и риск обнажить слабость властолюбца.

Нельзя не заметить, что даже, казалось бы, незначительная ненависть, защитно проецируемая вовне, суммируясь в обществе, оставляет глубокий отпечаток на социальных отношениях. Мы даже не говорим о насилии и социальных конфликтах: это слишком очевидно. Речь о другом: ценности престижа и властолюбия, разросшиеся в обществе эгоизм и социальное равнодушие, карьеризм и культ вещей - всё это застывшие отголоски базовой ненависти, идущей из глубин человеческого существа. Нет нужды рассуждать, насколько эти тренды современности разъедают целостность человека, катализируя укрепление ненавистнического фона в обществе.

А. Адлер, также как и Хорни полагавший, что главное в человеке - его включённость в социум, связывал ненависть и её проявления исключительно с идеей приспособления человека к жизни в обществе. В целом, он не заострял отдельного внимания на этой страсти, однако сделал несколько тонких замечаний по поводу её внешних проявлений. В частности, «ненависть мастерски владеет искусством маскировки», проявляясь в очень завуалированных, трудно распознаваемых формах, таких как критицизм, халатное отношение к делам и людям и даже «мизантропический» выбор профессии [25].

Итак, природа ненависти социальна. Именно этот аспект Адлер, Хорни и многие другие неофрейдисты выдвигали на первый план. И это положение фундаментально: ненависти нет вне общества. И наоборот: где есть общество, есть и ненависть. Она заложена в ткань человеческой социальности самой природой отношений между людьми. Социальный антагонизм, вражда существовали с древних времён и служили отправной точкой в восприятии любых чужаков, а отношения среди «своих» всегда были склонны оборачиваться расслоением и социальным неравенством, порождая зависть, ненависть и месть.

Как показали неофрейдисты, социальные аспекты ненависти всегда означают адаптацию человека в социуме и определённую адресацию этого чувства: ненависть всегда персонализована, направлена против кого-либо или чего-либо. Она есть отношение и обращение, выраженное, как правило, на языке эмоций. Даже когда это чувство направлено против себя самого, то и здесь мы видим форму обращения - но только к самому себе.

Социальная природа ненависти раскрывается не только в обращённости, но и в близости и привязанности к своему объекту. На первый взгляд, это не очевидно и странно. Ведь ненависть есть вражда: она отталкивает, заставляет избегать и отступать. И вместе с тем вражда притягивает: заставляет преследовать и нападать - впрочем, с од- 
ной лишь целью: унизить, уничтожить, не видеть. Анализируя эту мнимую странность, мы обнаруживаем, что независимо от поведенческих установок и стиля внешнего реагирования, ненависть всегда является силой притяжения. Если мы заглянем глубже во внутренний мир человека, в его ментальную «топографию» объектов реальности, мы обнаружим, что значимость объектов ненависти столь же велика, сколь и объектов любви: человек к ним так же крепко привязан. Именно это выразил Монтень ещё в XVI в.: «Раз мы ненавидим что-либо, значит, принимаем близко к сердцу».

Современный психоаналитик О. Кернберг, исследовавший «градации» ненависти в норме и патологии, писал: «В глубине души человек нуждается в объекте и вожделеет к нему и так же точно нуждается в его разрушении и вожделеет этого» [16, с. 37]. Вне сомнения, ненависть несёт в себе и эту двойственность. И чем сильнее эта страсть, тем больше в ней двойственной привязанности к объекту. Но какова природа этой двойственности? Фрейдистское объяснение мы могли бы найти через понятие катексиса: психическая энергия проявляет себя в виде зарядов, своего рода «квантов», стремящихся быть инвестированными в объект. Присутствие самой энергии страсти, сосредоточенной на объекте, как раз указывает на его значимость, а отнюдь не на его безразличие. И ключ к разгадке этой фиксации нужно искать в ранних объектных отношениях, связанных, в первую очередь, с амбивалентными отношениями с матерью. Объект вражды столь же ненавистен, сколько мог бы быть любимым.

Однако, перевод данного рассуждения в социальную плоскость приведёт нас к расширительному толкованию данной близости. Здесь нам интересен вопрос социально-культурных ценностей, аксиологического личностного ядра. Объект ненависти является нам небезразличным в силу его определённого взаимоотношения с ценностями, имеющими для нас высокий ранг. Вступая на поле наших ценностей, наш враг становится важным «игроком» в этом поле. Он глубоко затрагивает наши святыни: либо угрожая их существованию, либо, напротив, пытаясь символически их отобрать, как бы присваивая себе наше законное место в обладании ими. В первом случае речь может идти о подлинной ненависти, во втором - о тайной зависти. Ф. Ницше считал ненависть подлинной только к «достойному» врагу: «Мы не ненавидим ещё человека, коль скоро считаем его ниже себя, мы ненавидим лишь тогда, когда считаем его равным себе или выше себя» [26, с. 304]. Всё, что «выше» нас, олицетворяет наши идеалы. Всё, что «ниже», - не достигает наших ценностей, и Ницше называл этот случай не ненавистью, а презрением. «Мелкую» ненависть, прячущую под собой зависть, он именовал рессентиментом - мощным явлением, бичом культуры и её упадком.

\section{Между природой и свободой: шаг к философской антропологии}

Э. Фромм, выдающийся психоаналитик и философ, один из основателей неофрейдизма, сделал новый шаг в понимании негативных страстей человека. Хотя он, в отличие от Хорни, не фокусировал внимание на ненависти как таковой, ему принадлежит фундаментальное исследование человеческой деструктивности в целом, позволившие ему совершить определённые прорывы в понимании человеческой сущности. Нам, в свою очередь, это позволяет раздвинуть горизонты в понимании ненависти как целостного феномена.

Фромм отталкивался от принципа «социобиологического историзма» [1, с. 24]. Как следует из названия, он не умалял ни роли биологического, ни социального в человеке, однако предостерегал от опасности абсолютизации любого из этих подходов. Преодолевая ограниченность каждого из них, он рассматривал человеческое заведомо шире, чем обычно это происходило в каждой из названных парадигм.

Так, говоря о биологическом в человеке, с одной стороны, он не отрицал и даже подчёркивал конструктивную роль природной агрессии: в своём «доброкачественном» варианте она необходима для защиты и мобилизации, как это изначально происходит у животных. Однако здесь мыслитель обращает наше внимание на то, что в дикой природе, где много агрессии, нет ни ненависти, ни злобы. Все агрессивные порывы животных сугубо инструментальны, и их хищническое поведение не имеет ничего общего с таковым в человеческом мире, где хищничество начинает означать ненависть, эксплуатацию и унижение себе подобных. Категория зла возникает только применительно к человеческому и именно на фоне отрыва человека от сугубо биологического существования. Лишь у человека агрессия становится «злокачественной».

Ещё один момент отличия человека от животных - в его способности отрицать в себе био- 


\section{Психопатология повседневности}

логическое начало: человек часто действует далеко не ради его удовлетворения и даже абсолютно вопреки ему. Фромм приходит к важному выводу, что чувства и страсти имеют над человеком гораздо большую власть, чем просто животные порывы. Человек стремится переживать «самые острые, самые мощные потрясения бытия», преодолеть «банальное существование» и «перейти в трансцендентное бытие». Он не так страдает от голода, как от жизни, лишённой драматизма любви и ненависти. Он способен на самоубийство - но не по причине неудовлетворённой сексуальности, а от несчастной любви. И, наконец, он способен на убийство - но чаще всего не ради пищи или самозащиты, а исходя из определённой ненавистнической идеологии.

Фромм расширяет понимание человеческого и в отношении влияния среды. Безусловно, окружающая среда - неминуемый фактор существования человека. Рождаясь, человек присоединяется к биологическому роду Ноmо, и лишь подвергаясь влиянию общества и культуры, он очеловечивается. Однако даже разворачивая нас к пространству экзистенции и говоря о специфичных для человека «экзистенциальных потребностях», Фромм указывает на их культурно-социальный источник. Он пишет, что они «определяются специфическими условиями человеческого существования». Именно в культурной среде человек обретает устойчивую личностную структуру - характер, который затем ограничивает спектр его страстей и определяет доминанты, такие как любовь или ненависть. Подобный акцент на влиянии среды, как мы помним, сделан и у Хорни. Однако Фромм здесь идёт гораздо дальше: в его картине человек - не производная от обстоятельств и не их жертва, хотя жизнь, оказывая мощный прессинг, ставит человека именно в такие рамки. Человек - обладатель свободы, он и творец, и разрушитель. И Фромм помещает первопричину деструктивного внутрь человеческого существа: «виною всему мы сами, вернее, созданные нами социальные, политические и экономические обстоятельства». Человек творит свой мир, задаёт условия своего существования, выбирает ценности и конструирует смыслы. Как пишет Фромм, человек - не марионетка, «которой управляют либо инстинкт, либо воспитатели» [1, с. 75]: он сам принимает участие в своей жизни, обладает свободой поступков и несёт за них ответственность.

Итак, человек существо не только природное и социальное, но и экзистенциальное.
Человеческие страсти экзистенциальны: они являются выражением стремления человека придать смысл своему бытию. Без этого смысла человек не будет ощущать себя человеком. Как любовь и созидательность, так и ненависть, и тяга к разрушению могут стать смыслообразующим началом в человеке. Ненависть в свете этой парадигмы представляется нам одним из измерений для разворачивания человеческой экзистенции: она вырастает из поиска смысла и обретения ценностей, выступает как выплеск стремления обрести и реализовать смысл ради определённых идеалов. Она есть ценностное отношение к миру - реальным или мнимым врагам, идейным противникам, не чтящим или грозящим разрушить наши ценности. Она есть страж наших святынь, равно как и наших невротических устремлений. Ненависть гражданской войны, ненависть джихада или ненависть невротического нарциссизма, - все эти чувства роднит ценностная сила, стремящаяся развернуться в пространстве субъектности. По сути, ненависть - это универсальная ценностно-смысловой «механизм» человеческой субъектности, облечённый в чувственную, аффективную оболочку и являющийся единицей определённой культуры.

Говоря о пространстве человеческой свободы и культуры, мы приходим к выводу, что ненависть не «навязана» человеку как некое изначальное зло и разрушительная сила. Равно как и само зло - не дано человеку «свыше» как некое бремя. Вспоминая рассуждения великих философов о происхождении зла - Канта, Бердяева, Лосского - мы прежде всего говорим о человеческой свободе: ведь она является и бременем, и возможностью одновременно. Она величайший шанс и огромнейший риск для человеческой природы. Совершая акт свободы, человек ставит себя на грань произвола. И ненависть в этом смысле - и своего рода акт свободы, и, чаще всего, акт злоупотребления человеческой свободой. Но парадоксальность феномена ещё и в том, что, будучи порождённым свободой, он, аффективно развёртываясь, заходит в тупик: аффект закабаляет, особенно когда он является частью невротической системы, элементом жёсткой структуры характера. В этом смысле ненависть чаще всего - тупик свободы. Но есть и случаи, когда ненависть - достойный выразитель свободного начала в человеке: это ненависть, лежащая в основе созидания, свершений и подвигов. Однако для этого нужна любовь: именно она, как движение к определённым ценностям, способна призвать ненависть на свою службу - призвать как 
мощную силу, как энергию свободы. Именно тогда человеческая природа восполняет себя, реализуясь через творчество смыслов и их осуществление. Или не восполняет, остаётся ущербной, цепляясь за суррогаты ценностей и ощущая вечный экзистенциальный голод, ищущий насыщения в ненависти и разрушении.

\section{«Смысл» ненависти}

Если бы мы попытались дать определение ненависти, то среди прочих аспектов этого комплексного феномена, мы, вероятно, дали бы трактовку той роли, которую она играет в жизни человека. Переводя на язык экзистенциальной рефлексии, мы моги бы сказать об определённом смысле или даже символическом сообщении, которое ненависть транслирует своему адресату путём языка переживаний, чувственных образов, аффективной экспрессии или выстраиваемой содержательной идеологии. Как писал А. Глюксманн, ненависть это дискурс [27]. За наплывом чувств скрывается ткань социального отношения, наполненного смыслами и транслирующего определённое послание. О. Кернберг подчёркивал, что в ненависти всегда есть стойкое «когнитивное содержание», что, собственно, и отличает ненависть от взятых в отдельности аффектов ярости и гнева. Именно это содержание и пускает в человеке корни столь глубоко, дорастая, по словам Кернберга, до «мстительного триумфа» [16, с. 43] над объектом.

Так чем же наполнено содержание? И зачем вообще «нужна» ненависть - это бремя и это проклятие? Здесь мы намерены лишь подытожить уже многое сказанное в этой статье. И поскольку ненависть в норме и патологии разворачивается по разным сценариям, мы последовательно обобщим и то и другое.

Итак, в ходе разбора психоаналитических концепций ненависти, мы убедились, что сама по себе ненависть - ещё не болезнь и не зло. Прежде всего мы описывали идею Фрейда, в которой ненависть выступает началом самоутверждения младенца в мире. «Посылая» в виде крика сигналы неприятия и гнева, ребёнок усиливает свои позиции в этом мире, инвестируя в каждый подобный акт немалый заряд той природной энергии, который он черпает из резервуара влечений. Индивидуальность с самых истоков своего становления стремится к проявлению себя в пространстве социальности. Внешние угрозы этому формирующемуся Я, его жизненному пространству - маленький индивид принимает агрессивно. Именно на одном из полюсов этой агрессии на страже стоит ненависть. В этой роли она - крайнее, страстное и яростное проявление воли к отстаиванию своего пространства, своего права на жизнь и индивидуальность. Здесь впервые проявляется «человек ненавидящий»- но это лишь временно обострённая ипостась, важная фигура в сложной драме душевного становления. Ненависть здесь - это страж зарождающегося Я: на ранних этапах онтогенеза она играет исключительно благотворную и незаменимую роль.

В психоанализе едва ли звучит тема ненависти на более поздних стадиях становления человеческой психики. Но мы не можем не вспомнить, что «человек ненавидящий» вновь проявит себя и на последующих ступенях: особенно ярко - в пубертатный период, достигая крещендо юношеского максимализма, где душа вновь будет «тестировать» свои силы и пробовать на вкус границы мира и границы познания.

Однако сыграв важную роль на определённых этапах психосоциального развития, ненависть призвана отступить. Выполняя роль своего рода «запасных войск», она может быть по-настоящему востребована только в экстремальных или пограничных ситуациях жизни. В условиях угрозы жизни, ценностям бытия и своеобразия индивида, его человеческому достоинству «человек ненавидящий» как служебная ипостась вновь проступает теперь уже как хранитель смысловой целостности человека, страж его святынь. Здесь ненависть выступает ценностным посланием в мир, своего рода аксиологическим ультиматумом в адрес угрозы. И, в то же время, это энергетический ресурс, мобилизующий человека и фокусирующий его силы в целевой точке. Борьба с врагом, стихийными и социальными бедствиями, опасными болезнями - здесь ненависть, волна здоровой злости, «благородная ярость» являются верными союзниками. Как писал венгерский психоаналитик М. Балинт, у «здорового» взрослого ненависть «является лишь чем-то потенциальным или случайным; если для неё имеется действительно серьёзный повод, то может возникнуть и сохраняться сильное, порой огромное возбуждение, однако его нельзя уже приравнять к острой вспышке ярости. В противоположность любви ненависть должна исчезать легко и быстро, как только ситуация меняется к лучшему» [цит. по: 28, с. 120]. Ненависть, как и другие негативные страсти, не имеют безусловной власти 


\section{Психопатология повседневности}

над зрелым индивидом. Спонтанности ненавистнических выплесков здесь противопоставлена способность к любви: контакт человека с той базовой любовью к бытию, миру, ценностям, которая заложена в основы человеческого существа. Жизнь людей, общества немыслима без любви, внимания и заботы, и великим благом является то, если человеку доступны способности к терпению, благодарности, «смягчению ненависти любовью», говоря словами М. Кляйн.

Иную картину мы видим при ранней фрустрации структуры чувств. М. Кляйн, К. Хорни и других психоаналитики, исследовавшие ненависть в патологии, говорят о незрелом Я. Разные школы по-разному объясняют генезис состояния незрелости, однако они единогласны в том, что нездоровая ненависть - источник деструктивности и деградации человеческой природы. Человек теряет открытость миру, становится отрезанным от людей. Как писал израильский философ Мартин Бубер, «ненависть слепа» - ведь ненавидеть можно лишь «часть существа». Объект ненависти спрятан от ненавистника: чаще всего ему доступен лишь его ущербный образ, имаго, сотканное из проекций собственного бессознательного. В крайних проявлениях ненависти этот образ радикально обесценен, демонизирован, обращен в сторону абсолютного зла. Человек же, движимый ненавистью, обречён жить во вражде, довольствуясь, по выражению современного психиатра У.Гэйлина, «искаженным миром собственных восприятий» [цит. по: 29, с. 8]. И здесь «человек ненавидящий» проступает уже далеко не как органичная ипостась человеческого, а уже как особый антропологический тип. Выкристаллизованная в нём ненависть составляет основу его отношений с миром, хотя, безусловно, она глубоко вытеснена, отрезана от сознания. Дефицит любви и сострадания, эгоизм и обострённый нарциссизм, тщеславие, жадность и завистливость, спонтанные выплески злобы, - таковы главные штрихи к его портрету. Подобный способ существования в мире часто прячется под иными страстями и устремлениями, которые, на первый взгляд, имеют не так уж много общего с ненавистью: карьеризм, властолюбие, потребительский фетишизм и ряд других «болезней» цивилизованного общества. Однако маскировка базовой ненависти - один из регуляторов общественной жизни, в своей праоснове таящей «войну всех против всех». Поэтому пролиферация подобных страстей лишь заглубляет ненавистнический базис общества. Современные социокуль- турные реалии, без сомнения, продолжают культивировать враждебный антропотип, несмотря на всё усиливающиеся призывы к толерантности. Образы конкуренции и борьбы, доминирующие в мировой экономике и политике, - это своего рода выражения ненавистнического в человеке. И такое положение вещей знаменует собой несвободу от страстей и навязанных шаблонов, уход людей от их подлинной самоидентичности, творческой и духовно развёрнутой жизни.

Вероятно, даже в патологической гипертрофии ненависти есть свой содержательный посыл, символически выраженный на языке разнообразных симптомов враждебности. Возвращаясь к рамкам нашего разговора, заметим, что прерогативой психоанализа и является дешифровка этого языка. Хороший аналитик способен увидеть за знаками ненависти глубоко упрятанную драму личностного раскола, несостоявшееся Я, не-проживаемую жизнь. При этом, на наш взгляд, он обязан держать во внимании многослойную природу феномена. Это означает, что он должен рассмотреть ненависть по крайней мере в двух ракурсах. С одной стороны, безусловно, ненависть есть результат ранней деформации структуры чувств человека, который выступает здесь лишь жертвой травматичных обстоятельств. Прежде всего такому человеку был бы полезен «проводник» в тёмные дебри его бессознательного, где кроются отщеплённые истоки враждебности. И психоаналитик может оказаться помощником в том, чтобы высветить и разорвать фиксацию на травмирующих объектных отношениях, дать ход интеграции ненависти с любовью, а также - место живым переживаниям, долго находившимся под запретом. Однако с другой стороны, вслед за Фроммом, следует помнить и об экзистенциальной стороне вопроса. И она здесь, возможно, более важная. Ведь именно эта сторона подразумевает возможность собственного, осознанного ресурса человека, достаточного для того, чтобы самому справиться со своей ненавистью. В этом ракурсе ненависть - это не только тяжёлое наследие индивидуального психологического прошлого, но и выбор человека, отчасти - свободный. Человек здесь - не жертва, а активный субъект, ответственный, по крайней мере, за свою жизнь. Элементом выбора на первом этапе может стать сознательное отношение к ненависти: не как к обыденной норме, а как к сигналу своей деструктивности и отклонения от подлинной природы его собственной индивидуальности. Сам факт глубокой осознанности 


\section{Психология и психотехника 10(85) • 2015}

по отношению к своей ненависти уже противостоит её бессознательной власти. Ведь в определённом смысле ненависть - это суррогат осознанного дискурса: проявленная на языке аффекта, смутных ощущений и тёмных порывов, она являет собой нечто невыраженное и недосказанное, томящееся по своей возможной дешифровке. Ненависти есть что сказать. Но ненавистнику требуется мужество, для того, чтобы пробиться к этому посланию, выслушать и принять его. Чем глубже ненависть, тем она менее осознанна, и тем сложнее признать сам факт её существования. Что же касается роли психоаналитика, то препарирование бессознательных глубин здесь необходимо, но недостаточно. Ракурс работы становится экзистенциальным. Другими словами, аналитик здесь призван помочь пациенту открыть собственные вершины духа, наполниться решимостью самостоятельно найти у себя те степени личностной свободы, которые у любого человека, безусловно, есть.

\section{Список литературы:}

1. Фромм Э. Анатомия человеческой деструктивности. М.: Республика, 1994.

2. Кант И. Антропология с прагматической точки зрения. СПб.: Наука, 1999.

3. Куттер П. Любовь, ненависть, зависть, ревность. Психоанализ страстей. СПб.: Б.С.К., 1998.

4. Феррис П. Зигмунд Фрейд. М.: Попурри, 2001.

5. Шпильрейн С. Деструкция как причина становления // Шпильрейн С. Психоаналитические труды. Ижевск: ERGO, 2008.

6. Фрейд 3. Три очерка по теории сексуальности // Фрейд 3. Психология бессознательного. М.: Просвещение, 1990.

7. Фрейд 3. Анализ фобии пятилетнего мальчика // Фрейд 3. Психология бессознательного. М.: Просвещение, 1990.

8. Фрейд 3. Тотем и табу. Психология первобытной культуры и религии. СПб.: Алетейя, 1997.

9. Семушкин А.В. Эмпедокл. М.: Мысль, 1985.

10. Шеллинг Ф.В. Философские исследования о сущности человеческой свободы и связанных с ней предметах // Шеллинг Ф.В. Собр. соч. в 2 т. Т. 2. М.: Мысль, 1989.

11. Соловьёв В.С. Духовные основы жизни // Соловьёв В.С. Собрание сочинений: в 10 т. Т. 3. СПб.: Книгоизд. тов-во «Просвещение», 1911.

12. Фрейд 3. Влечения и их судьба // Фрейд 3. Основные психологические теории в психоанализе. Очерк истории психоанализа. СПб.: Алетейя, 1998.

13. Фрейд 3. Неизбежна ли война? Письмо Альберту Эйнштейну // Фрейд 3. По ту сторону принципа удовольствия. М.: Прогресс, 1992.

14. Кляйн М. Ненависть, зависть, любовь, сочувствие. СПб.: Астер-Х, 2012.

15. Калшед Д. Внутренний мир травмы. М.: Академический проект, 2001.

16. Кернберг О. Агрессия при расстройствах личности и перверсиях. М.: Класс, 1998

17. Фрейд 3. По ту сторону принципа удовольствия // Фрейд 3. Психология бессознательного. М.: Просвещение, 1990.

18. Новейший философский словарь / Сост. А.А. Грицанов. Минск: Изд. В.М. Скакун, 1998.

19. Гуревич П.С. Психоанализ: в 2 т. Т. 2. М.: Магистр, 2014.

20. Винникотт Д. Разговор с родителями. М.: Класс, 2012.

21. Хорни К. Невроз и личностный рост. Борьба за самореализацию. СПб.: Б.С.К., Восточно-Европейский институт психоанализа, 1997.

22. Чугунова И.О. Лики ненависти: философско-антропологические размышления // Психология и психотехника. 2015. № 4. С. 383-391.

23. Шелер M. Ordo Amoris // Шелер М. Избранные произведения. М.: Гнозис, 1994.

24. Шёк Г. Зависть. М.: ИРИСЭН, 2010.

25. Адлер А. Понять природу человека. М.: Академический проект, 1997.

26. Ницше Ф. По ту сторону добра и зла // Ницше Ф. Сочинения в 2 т. Т. 2. М.: Мысль, 1990.

27. Глюксманн А. Философия ненависти. М.: АСТ, Транзиткнига, 2006.

28. Хоффмайстер М. Вклад Микаэла Балинта в теорию и метод психоанализа // Энциклопедия глубинной психологии: в 3 т. Т. 3. Последователи Фрейда. М.: Когито-Центр, 2002.

29. Royzman E., McCauley C.R. \& Rozin P. From Plato to Putnam: Four ways to think about hate // The psychology of hate / Sternberg R.J. (ed.). Washington, DC: APA, 2005.

\section{References (transliteration):}

1. Fromm E. Anatomiya chelovecheskoi destruktivnosti. M.: Respublika, 1994.

2. Kant I. Antropologiya s pragmaticheskoi tochki zreniya. SPb.: Nauka, 1999.

3. Kutter P. Lyubov', nenavist', zavist', revnost'. Psikhoanaliz strastei. SPb.: B.S.K., 1998.

4. $\quad$ Ferris P. Zigmund Freid. M.: Popurri, 2001. 


\section{Психопатология повседневности}

5. Shpil'rein S. Destruktsiya kak prichina stanovleniya // Shpil'rein S. Psikhoanaliticheskie trudy. Izhevsk: ERGO, 2008.

6. Freid Z. Tri ocherka po teorii seksual'nosti // Freid Z. Psikhologiya bessoznatel'nogo. M.: Prosveshchenie, 1990.

7. Freid Z. Analiz fobii pyatiletnego mal'chika // Freid Z. Psikhologiya bessoznatel'nogo. M.: Prosveshchenie, 1990.

8. Freid Z. Totem i tabu. Psikhologiya pervobytnoi kul'tury i religii. SPb.: Aleteiya, 1997.

9. Semushkin A.V. Empedokl. M.: Mysl', 1985.

10. Shelling F.V. Filosofskie issledovaniya o sushchnosti chelovecheskoi svobody i svyazannykh s nei predmetakh // Shelling F.V. Sobr. soch. v 2 t. T. 2. M.: Mysl', 1989.

11. Solov'ev V.S. Dukhovnye osnovy zhizni // Solov'ev V.S. Sobranie sochinenii:v 10 t. T. 3. SPb.: Knigoizd. tov-vo «Prosveshchenie», 1911.

12. Freid Z. Vlecheniya i ikh sud'ba // Freid Z. Osnovnye psikhologicheskie teorii v psikhoanalize. Ocherk istorii psikhoanaliza. SPb.: Aleteiya, 1998.

13. Freid Z. Neizbezhna li voina? Pis'mo Al'bertu Einshteinu // Freid Z. Po tu storonu printsipa udovol'stviya. M.: Progress, 1992.

14. Klyain M. Nenavist', zavist', lyubov', sochuvstvie. SPb.: Aster-Kh, 2012.

15. Kalshed D. Vnutrennii mir travmy. M.: Akademicheskii proekt, 2001.

16. Kernberg O. Agressiya pri rasstroistvakh lichnosti i perversiyakh. M.: Klass, 1998.

17. Freid Z. Po tu storonu printsipa udovol'stviya // Freid Z. Psikhologiya bessoznatel'nogo. M.: Prosveshchenie, 1990.

18. Noveishii filosofskii slovar' / Sost. A.A. Gritsanov. Minsk: Izd. V.M. Skakun, 1998.

19. Gurevich P.S. Psikhoanaliz: v 2 t. T. 2. M.: Magistr, 2014.

20. Vinnikott D. Razgovor s roditelyami. M.: Klass, 2012.

21. Khorni K. Nevroz i lichnostnyi rost. Bor'ba za samorealizatsiyu. SPb.: B.S.K., Vostochno-Evropeiskii institut psikhoanaliza, 1997.

22. Chugunova I.O. Liki nenavisti: filosofsko-antropologicheskie razmyshleniya // Psikhologiya i psikhotekhnika. 2015 . № 4. S. 383-391.

23. Sheler M. Ordo Amoris // Sheler M. Izbrannye proizvedeniya. M.: Gnozis, 1994.

24. Shek G. Zavist'. M.: IRISEN, 2010.

25. Adler A. Ponyat' prirodu cheloveka. M.: Akademicheskii proekt, 1997.

26. Nitsshe F. Po tu storonu dobra i zla // Nitsshe F. Sochineniya: v 2 t. T. 2. M.: Mysl', 1990.

27. Glyuksmann A. Filosofiya nenavisti. M.: AST, Tranzitkniga, 2006.

28. Khoffmaister M. Vklad Mikaela Balinta v teoriyu i metod psikhoanaliza // Entsiklopediya glubinnoi psikhologii: v 3 t. T. 3. Posledovateli Freida. M.: Kogito-Tsentr, 2002.

29. Royzman E., McCauley C.R. \& Rozin P. From Plato to Putnam: Four ways to think about hate // The psychology of hate / Sternberg R.J. (ed.). Washington, DC: APA, 2005. 